\title{
ATP-BIOLUMINESCENCE ASSAY AS AN ALTERNATIVE FOR HYGIENE-MONITORING PROCEDURES OF STAINLESS STEEL MILK CONTACT SURFACES
}

\author{
Patrícia Dolabela Costa; Nélio José Andrade*; Sebastião César Cardoso Brandão; Frederico José Vieira Passos; \\ Nilda de Fátima Ferreira Soares
}

Departamento de Tecnologia de Alimentos, Universidade Federal de Viçosa, Viçosa, MG, Brasil

Submitted: June 14, 2004; Approved: May 06, 2006

\begin{abstract}
ATP-bioluminescence assay was used to evaluate the cleaning and sanitizing procedures of stainless steel milk contact surfaces. Surfaces of a raw milk transportation tank, a raw milk cooling storage tank, an equalization pasteurizing tank, a pasteurized milk storage tank and a pasteurized milk packaging tank, as well as a milk centrifuge were evaluated. The Relative Light Unit (RLU) using a commercial luminometer and mesophilic aerobic counts $\left(\mathrm{CFU} . \mathrm{cm}^{-2}\right)$ on surfaces were determined. There were no significant differences $(\mathrm{p}>0.05)$ in RLU on the assessed surfaces before and after the cleaning and sanitizing procedures. Also, there were no significant differences ( $p>0.05)$ in $\mathrm{CFU} . \mathrm{cm}^{-2}$ on the surfaces before the cleaning and sanitizing procedures, whereas different bacterial numbers were found on surfaces after the hygiene procedures. The surfaces of the milk centrifuge, raw milk cooling tank and milk packaging tank showed the largest mesophilic aerobic numbers after the hygiene, reaching $2.21,2.18$, and $1.21 \log _{10}$, respectively. The results demonstrated that there is no agreement among the techniques for classification of hygienic conditions of the evaluated surfaces, showing a non-direct relation between RLU and CFU. $\mathrm{cm}^{-2}$. The ATP-bioluminescence method showed that $100 \%$ of the surfaces were under inadequate hygiene conditions, while the plate count method detected only $50 \%$, based on the APHA's recommendation, and 33\%, based on the WHO's recommendation. High variations in RLU measurements were observed, suggesting the need for more than only one surface analysis. The ATPbioluminescence is not a direct replacement for microbiological testing, but provides complementary information and should be used as part of an integrated strategy.
\end{abstract}

Key words: dairy plant, cleaning and sanitizing procedures, food processing surfaces, ATP hygienemonitoring system, ATP-bioluminescence

\section{INTRODUCTION}

The development of new products and new food processing technologies, the increase in trade among countries, the concern about food safety and the increase in reports on food-borne disease outbreaks have shown that the implementation of more effective and rigorous hygiene procedures is fundamental to the milk processing industry. Thus, the dairy food industry has been seeking rapid and sensitive techniques to assess hygienic conditions of milk processing contact surfaces. Traditional microbiological analyses require long time to complete, making it more difficult to control cleaning and sanitizing procedures. Pasteurized milk shelf life is affected mainly by postpasteurization bacterial contamination. The occurrence of several microorganisms, such as Pseudomonas ssp. on milk processing systems is probably due to inadequate hygiene procedures (14). Dairy industries and other food industries have benefited from new rapid methods for the evaluation of hygienic condition of food processing surfaces. Microorganisms that are not removed from the surfaces may trigger microbial adherence and biofilm formation $(1,2,3,8,18,19,20)$ and migrate from the surfaces to the food causing contamination. Rapid methods based on microbial

*Corresponding Author. Mailing address: Departamento de Tecnologia de Alimentos, Universidade Federal de Viçosa. 36570-000, Viçosa, MG, Brasil. Tel.: (+5531) 3899-1855, Fax: (+5531) 3899-2208. E-mail: nandrade@ufv.br 
growth and metabolisms have been developed using principles of ATP-bioluminescence, biophysics, radiometry and impedance measurement. ATP-bioluminescence assay detects the ATP amount on the contact surfaces in food processing systems, as well as in food samples $(4,5,6,12,16)$. The ATP detected by this technique is derived from microorganisms, somatic cells, plants and animals. A number of instruments using ATPbioluminescence principles are commercially available: ATP reacts with the luciferin-luciferase enzymatic complex and the light emitted is measured by a luminometer and expressed in Relative Light Units (RLU) (4). The higher the amount of ATP on the surface or food samples, the higher the light output expressed in Relative Light Unit (RLU).

The swab technique was the major alternative from the 1900s to the late 1980s. Rapid methods such as ATP bioluminescence and proteins residues have been developed since then. These methods detect food/organic debris rather than microorganisms and offer proactive cleanliness management with results available in real time (11). According to results of the assays, corrective action can be taken, including recleaning prior to surface use. Some traditional microbiologists still feel safer with assessing surface microbial contamination, but nowadays there is a lot of concern about food allergens, which may remain on surface and cross-contaminate other foods whose microbial counts are not possible of detection if cleaning is inadequately performed.

In food processing, there is often little value in trying to directly correlate microbial surface counts to ATP measurements, since the ratio between microbial number and food debris is not constant, not providing a strong mathematical correlation between both techniques (11). However, in specific situations, this mathematical correlation should be considered. For example, on the internal surfaces of the equipment to produce UHT (Ultra High temperature) milk, high ATP counts and low microbial counts are found, therefore, an increase in milk residues can increase the bioluminescence measurement but not the microbial number. Similarly, ATP counts on raw food surfaces increase with higher increases in microbial numbers.

Finally, it should be considered that rapid chemical tests are not a direct replacement for microbiological tests but provide complementary information and should be used as part of an integrated strategy.

The aim this work was to evaluate the use of ATP bioluminescence to assess the hygiene of stainless steel equipment surfaces during routine conditions of a dairy plant. In addition, it was sought to evaluate the agreement, but not the mathematical correlation, between ATP measurement and microbial counts.

\section{MATERIALS AND METHODS}

\section{Surfaces}

The stainless steel surfaces of six pieces of equipment, including raw milk transportation tank, raw milk cooling tank, equalization tank for milk pasteurization, milk centrifuge, pasteurized milk storage tank and pasteurized milk packaging tank, were evaluated at a dairy plant, which processes approximately 10,000 L of milk and manufactures daily skim milk, whole milk, yogurt, butter, doce de leite (a typical LatinAmerican treat made by concentration of milk and sugar). The surfaces were sampled before and after the hygiene procedures using the swab technique (18) and the ATP-bioluminescence assay (5), with a Uni-Lite Xcel luminometer (Biotrace Ltd.) (5). The major concepts of good manufacturing practices (GMP) were adequately applied at the dairy plant, however the HACCP (Hazard Analysis by Critical Control Point) was in an initial stage.

\section{Hygiene procedures}

All surfaces were subjected to the following basic cleaning and sanitizing procedures: pre-rinse with water $\left(35-40^{\circ} \mathrm{C}\right)$ for 1 min; surface clean by circulating or spraying with spray ball $1.0 \% \mathrm{NaOH}$ at $80^{\circ} \mathrm{C}$ for $20 \mathrm{~min}$; surface washing for removal of alkali residues with water at $20-25^{\circ} \mathrm{C}$, and sanitizing by circulating or spraying water at $70^{\circ} \mathrm{C}$ for $2 \mathrm{~min}$; the surfaces were air dried.

\section{Sampling for microbiological and bioluminescence analysis}

The samples for analysis were collected before and after the cleaning and sanitizing procedures. Cotton swabs for the microbiological analysis were $0.5 \mathrm{~cm}$ in diameter, $2 \mathrm{~cm}$ in length, with haste $12 \mathrm{~cm}$ in length and sterilized at $121^{\circ} \mathrm{C} / 15 \mathrm{~min}$. The swabs were first moistened in $10 \mathrm{~mL}$ of a $0.25 \%$ sodium thiosulphate neutralizing solution, previously sterilized at $121^{\circ} \mathrm{C} / 15 \mathrm{~min}$, contained in $15 \times 180 \mathrm{~mm}$ assay glass tubes. The excess buffer was pressed out against the inside wall of the tube. The microorganisms, adherent or not, were recovered by rubbing the swabs twice, at a $30^{\circ}$ angle with the surface to be analyzed, covering a surface area of $100 \mathrm{~cm}^{2}(10 \times 10 \mathrm{~cm})$.

Afterward, the swabs were placed in the assay tubes containing $10 \mathrm{~mL}$ of neutralizer solution and agitated to release the cells removed from the surfaces. The tubes were shipped to the laboratory under refrigerated conditions. Volumes of $1 \mathrm{~mL}$ or $0.1 \mathrm{~mL}$ of adequate dilutions of the neutralizer solution containing microorganisms were plated on Count Agar (Merck) for mesophilic aerobic counts. The Petri dishes were incubated at $35^{\circ} \mathrm{C} / 48 \mathrm{~h}$ and the results expressed as $\log _{10}$ CFU.cm ${ }^{-2}$.

Hygiene procedures for the surfaces were also evaluated by ATP-bioluminescence. The total ATP on surfaces was detected by the Clean Test kit (5), following the same approach for mesophilic aerobics. Swabs were placed in a cuvette and the ATP sampled on surfaces reacted with the luciferin-luciferase enzymatic complex emitting light. The kits were transferred to the luminometer chamber and the bioluminescence measurements were determined after 10 seconds. The results were expressed as $\log _{10}$ RLU released by the total ATP. 
According to recommendations of the ATP-bioluminescence equipment manufacturer, measurements lower than $150 \mathrm{RLU}$ were considered clean, from 151 to 300 RLU were considered suspect, and values higher than 301 URL were considered inadequate hygienic conditions.

\section{Statistical analysis}

Three samples were collected on each surface for bioluminescence assays and one sample for microbiological analysis. The experiment was repeated three times. Data were evaluated by analysis of variance followed by Tukey's test at $5 \%$ probability level.

\section{RESULTS AND DISCUSSION}

No significant differences were found ( $p>0.05$ ) for RLU on surfaces evaluated before and after the cleaning and sanitizing procedures at the dairy plant (Table 1). There was a high variation in RLU measurements, which resulted in high standard deviations from the mean and consequently no statistical differences were detected by the analysis. This high variation in RLU measurements may be interfering with the assessment of hygienic conditions of food contact surfaces. Some ATP kits emitted bioluminescence even before use, and it has been suggested that this interference in the light measurements could increase the RLU values (14). The RLU measurements are more likely to be a reflection of how the cleaning and testing have been performed rather than ATP test systems, which should be able to discriminate between a well and an inadequately cleaned surface (11).

In our experiment, the influence of chemical agent residues, basically sodium hydroxide applied to remove organic substances, such as proteins and fats from surfaces was not

Table 1. $\log _{10}$ of RLU for total ATP on different equipment surfaces at a dairy plant before and after hygiene procedures. Means of three repetitions.

\begin{tabular}{lcc}
\hline \multicolumn{1}{c}{ Surfaces } & \multicolumn{2}{c}{ Means } \\
\cline { 2 - 3 } & Before & After \\
\hline Raw milk cooling tank & $4.60 \mathrm{Aa}$ & $3.95 \mathrm{Aa}$ \\
Milk centrifuge & $4.51 \mathrm{Aa}$ & $4.50 \mathrm{Aa}$ \\
Milk transportation tank & $4.07 \mathrm{Aa}$ & $4.07 \mathrm{Aa}$ \\
Milk packaging tank & $3.70 \mathrm{Aa}$ & $3.71 \mathrm{Aa}$ \\
Pasteurized milk tank & $3.61 \mathrm{Aa}$ & $3.70 \mathrm{Aa}$ \\
Milk equalization tank & $3.45 \mathrm{Aa}$ & $3.06 \mathrm{Aa}$ \\
\hline
\end{tabular}

Means followed by same capital letter in the rows and by same small letter in the columns, did not differ by the Tukey test at $5 \%$ probability level. evaluated, but some researches have demonstrated that the RLU measurement can be affected by chemical cleaning agents and commercial sanitizers $(9,10,13)$. An ATP extractant effect is attributed to detergents and sanitizers solutions used in cleaning and sanitizing procedures. A number of researches have demonstrated that such kind of chemicals can cause either quenching or enhancement of the ATP signal $(11,18)$.

In relation to traditional microbial counts, no significant differences ( $p>0.05)$ were found for CFU. $\mathrm{cm}^{-2}$ on the surfaces before cleaning and sanitizing procedures (Table 2). Different counts, expressed in CFU. $\mathrm{cm}^{-2}$, were found on surfaces after the hygiene procedures. The milk centrifuge, raw milk cooling tank and milk packaging tank surfaces showed the highest mesophilic aerobic counts after cleaning and sanitizing procedures, reaching $2.21,2.18$, and $1.21 \log _{10}$, respectively.

According to the results, there is no agreement between the techniques for classifying the hygienic condition of the assessed surfaces, which shows a non-direct relation between RLU and CFU.cm ${ }^{-2}$. Similar results were found in a study using three available commercial ATP-bioluminescence kits to evaluate hygienic conditions on equipment surfaces of a beer industry (15), in which it was not possible to find agreement between the ATP-bioluminescence technique and bacterial counts. Some researches consider that the ATPbioluminescence technique should be applied as a hygienic condition indicator of the amount of organic matter on surfaces $(18,19,20)$. This is important information, since nutrients on surfaces may support the bacterial adherence process and biofilm formation.

The mean values of the bacterial counts on all surfaces before and after hygiene procedures were $1.20 \times 10^{3} \mathrm{CFU} . \mathrm{cm}^{-2}$ and $1.10 \times 10^{1} \mathrm{CFU} . \mathrm{cm}^{-2}$ respectively, decreasing the number of the mesophilic aerobics in $99.1 \%$, whereas the mean values of

Table 2. $\log _{10}$ of CFU. $\mathrm{cm}^{-2}$ of mesophilic aerobic microorganisms on different surfaces of a milk circulation line at a dairy plant.

\begin{tabular}{lll}
\hline \multirow{2}{*}{ Surfaces } & \multicolumn{2}{c}{ Mean } \\
\cline { 2 - 3 } & Before & After \\
\hline Milk centrifuge & $3.59 \mathrm{Aa}$ & $2.21 \mathrm{Ba}$ \\
Raw milk cooling tank & $3.49 \mathrm{Aa}$ & $2.18 \mathrm{Ba}$ \\
Milk packaging tank & $3.20 \mathrm{Aa}$ & $-0.43 \mathrm{Bb}$ \\
Pasteurized milk tank & $3.03 \mathrm{Aa}$ & $-0.17 \mathrm{Bb}$ \\
Milk equalization tank & $2.72 \mathrm{Aa}$ & $1.21 \mathrm{Bab}$ \\
Milk transportation tank & $2.72 \mathrm{Aa}$ & $-0.96 \mathrm{Bb}$ \\
\hline
\end{tabular}

Means followed by same capital letter in the rows and by same small letter in the columns, did not differ by the Tukey test at $5 \%$ probability level. 
Table 3. Percentages of milk processing surfaces at a dairy plant considered under good hygienic conditions, according to the recommendations proposed by international agencies or the ATPbioluminescence equipment manufacturer

\begin{tabular}{|c|c|c|c|}
\hline \multirow{2}{*}{ Agency or manufacturer } & \multirow{2}{*}{ Recommendation } & \multicolumn{2}{|c|}{ Percentages } \\
\hline & & Before & After \\
\hline $\begin{array}{l}\text { American Public } \\
\text { Health Association }\end{array}$ & $\leq 2$ CFU.cm ${ }^{-2}$ & 0 & 50 \\
\hline World Health Organization & $\leq 50{\text { CFU } . \mathrm{cm}^{-}}^{2}$ & 0 & 67 \\
\hline Equipment Manufacturer & $\leq 150 \mathrm{URL}$ & 0 & 0 \\
\hline
\end{tabular}

RLU before and after cleaning were $3.99 \log _{10}$ and $3.83 \log _{10}$ respectively, slightly decreasing the bioluminescence measurement.

In addition, the results showed that the means of the mesophilic aerobic numbers after hygiene procedures were above 2 CFU. $\mathrm{cm}^{-2}$, higher than the American Public Health Association's (APHA) recommendation (7) for surfaces to be considered under adequate conditions for food processing. However, the numbers complied with the recommendation of 50 CFU. $\mathrm{cm}^{-2}$ proposed by the World Health Organization (WHO).

It could be concluded that the surfaces were under good hygienic conditions when the bacterial counts $\left(1.10 \times 10^{1} \mathrm{CFU} . \mathrm{cm}^{-2}\right)$ were compared to WHO's recommendations. However, the ATP bioluminescence technique showed that the surfaces were not in good conditions for food processing, since the RLU mean was $3.83 \log _{10}$, which is much higher than the recommendation (2.18 $\log _{10}$ RLU) by the kit manufacturer. The RLU measurement obtained from the assessment of the cleaning procedures needs to be compared with acceptable clean values (11). In this research, we chose the value recommended by the manufacturer, but other specifications can be proposed for the quality control of food industries. Griffith (11) recommends values lower than 500 RLU for a surface to be considered clean. To establish a standard for RLU measurement, two concerns should be considered. First of all, the value of RLU adopted need to be related to risk and should indicate if a surface is clean or not. In addition, the sampling should be representative of the surface.

Paez et al. (16) evaluated the hygiene conditions of milking equipment, bulk tanks and milk transport tanker using ATPbioluminescence and found that the outlet of the plate cooler, the outlet pipe of the bulk tank and the internal surface of the manhole lid of the milk transport tanks were the most critical points.

Odebretch et al. (15) evaluated the hygiene conditions of equipment surface in breweries applying bioluminescence methods and found that URL measurement did not correlate with the microbial counts. However, the authors suggested that bioluminescence is a suitable tool for monitoring the efficiency of cleaning and disinfection of tanks, pipelines and other brewery equipment.

ATP-bioluminescence and bacterial counts were also compared by determining the percentage of surfaces in good hygienic conditions indicated by the techniques. The ATPbioluminescence assay showed that $100 \%$ of surfaces evaluated were in inadequate hygienic conditions, whereas bacterial counts detected only $50 \%$ of surfaces in inadequate conditions, according to the APHA, or 33\%, according to the WHO.

These data are compatible with the hypothesis that the ATP-bioluminescence assay produces results different from bacterial counts, suggesting a probable influence of surface organic matter residues on the enzymatic reaction that produces the light signal measured by the luminometer.

There have been reports of results similar to our experiment (13). In this research, the hygienic conditions of 86 different surfaces of a line of fluid milk in 4 dairy plants were evaluated by the ATP bioluminescence technique and mesophilic aerobic counts. The ATP-bioluminescence assay showed that 69 surfaces $(64 \%)$ emitted $<100$ RLU, which according to the kit manufacturer is considered clean.

However, plate counts indicated that only 44 surfaces (65\%) showed bacterial contamination. Thus, bacterial counts prove to be more sensible than ATP-bioluminescence to evaluate if a surface is under good hygienic condition when RLU measurements are lower than 100 RLU. On 10 of the 11 surfaces considered under suspect hygienic conditions by ATPbioluminescence, the bacterial contamination was determined by plate counts. Forty-four surfaces were under inadequate hygienic conditions according to the ATP-bioluminescence. Microorganisms were detected on $78 \%$ of them, whereas it was not possible to detect any bacterial growth on $22 \%$. These results can be explained by the fact that the non-microbial origin ATP (such as somatic, plant and animal cells) is detected by techniques based on bioluminescence measurements. These types of ATP would be present on the assessed surfaces together with milk residues.

\section{CONCLUSIONS}

No agreement was found between the bioluminescence measurements and the mesophilic aerobic counts, in order to classify the hygienic conditions of stainless steel surfaces of a fluid milk processing line at a dairy plant, since there is a nondirect relation between RLU and CFU. $\mathrm{cm}^{-2}$. The ATPbioluminescence method showed that $100 \%$ of the surfaces were under inadequate hygiene conditions, while the plate count method detected only $50 \%$, based on the APHA's recommendation, and 33\%, based on the WHO's recommendation. ATP-bioluminescence proved to be a suitable complementary technique in the control of cleaning and sanitizing procedures. 


\section{ACKNOWLEDGEMENTS}

The authors would like to thank CNPq and FAPEMIG for the financial support.

\section{RESUMO}

\section{Técnica do ATP-bioliminescência como uma alternativa para o monitoramento do procedimento de higienização de superfícies de aço inoxidável na indústria de laticínios}

A técnica do ATP-bioluminescência avaliou os procedimentos de higienização de superfícies em aço inoxidável dos tanques de transporte de leite cru, de estocagem de leite cru resfriado, de equilíbrio de um pasteurizador, de estocagem de leite pasteurizado e para embalagem de leite pasteurizado e, ainda, a superfície interna de uma centrífuga de leite quanto à determinação de Unidades Relativas de Luz (URL) e da contagem de mesófilos aeróbios (UFC.cm ${ }^{-2}$ ). Não houve diferença significativa $(\mathrm{p}>0.05)$ na medida de URL nas superfícies antes e depois do procedimento de higienização. Também, não houve diferença significativa ( $p>0.05)$ no número de UFC. $\mathrm{cm}^{-2}$ nas superfícies antes da higienização. No entanto, contagens bacterianas diferentes foram constatadas após este procedimento. As superfícies da centrífuga e dos tanques de leite resfriado e para embalagem de leite apresentaram as maiores contagens após a higienização, atingindo $2,21,2,18$, e $1,21 \log _{10}$, respectivamente. Os resultados mostram que não há concordância entre os métodos na classificação das condições higiênicas das superfícies, indicando que não há relação direta entre RLU e UFC. $\mathrm{cm}^{-2}$. A técnica do ATP-bioluminescência indicou que 100\% das superfícies estavam em condições higiênicas inadequadas, enquanto a contagem bacteriana indicou apenas $50 \%$ de acordo com as recomendações da APHA e 33\% de acordo com OMS. Variações elevadas nas medidas de URL sugerem a necessidade de se realizar mais de uma análise na mesma superfície. A técnica do ATP-bioluminescência não deve simplesmente substituir os testes microbiológicos mas ser usada para se obter informações complementares para avaliar as condições higiênicas das superfícies para o processamento de leite.

Palavras-chave: indústria de laticínios, procedimentos de limpeza e sanitização, superfícies para processamento de alimentos, monitoramento da higiene por ATP-bioluminescência, ATP-bioluminescência

\section{REFERENCES}

1. Andrade, N.J.; Macedo, J.A. Higienização na indústria de alimentos. São Paulo: Editora Varela, 1996, 182p.
2. Akutsu, C.K. Adesão de esporos de Bacillus sporothermodurans ao aço inoxidável e sua resistência a sanificantes químicos em condições de uso simulado. Viçosa, MG 2001. 65p. (Dissertação de mestrado em Ciência e Tecnologia de Alimentos, Universidade Federal de Viçosa).

3. Bal A.; M.F.A.; Jamilah, D.; Marshall, D.L. Attachment of Aeromonas hydrophila to stainless steel surfaces. Dairy, Food Environ. Sanit., 18, 642-649, 1998.

4. Barrichello, A.; Allil, M.C.A. Bioluminescência: uma nova ferramenta para tornar o controle microbiológico mais rápido, fácil e preciso. Rev. Inst. Lat. Cândido Tostes, 52, 71-79, 1997.

5. Biotrace. BIOTRACE Xcel. [S.I]. 2000. (Manual técnico, 140p).

6. Colquhoun, K.O.; Timms, S.; Fricker, C.R. A simple method for the comparison of commercially available ATP hygiene-monitoring systems. J. Food Protec., 61, 499-501, 1998.

7. Evancho, G.M.; Sveum, W.H.; Moberg, L.J.; Frank, J.F. Microbiological monitoring of the food processing environment. In: Downes, F.P; Ito, K. Compendium of methods for the microbiological examination of foods. $4^{\text {th }}$. APHA, Washington, D.C., 2001, chapter 3, p.25-34.

8. Figueiredo, H.M.; Reis, R.C.; Andrade, N.J. Capacidade de adesão de diferentes microrganismos em sistema simulador de linha de processamento de leite. XX Congresso Brasileiro de Microbiologia, Salvador, 1999, p.383.

9. Green, T.A.; Russel, S.M.; Fletcher, D.L. Effect of chemical sanitizing agents on ATP bioluminescence measurements. J. Food Protec., 61, 1013-1017, 1998.

10. Green, T.A.; Russel, S.M.; Fletcher, D.L. Effect of chemical cleaning agents and commercial sanitizers on ATP bioluminescence measurements. J. Food Protec., 62, 86-90, 1999.

11. Griffith, C. Improving surface sampling and detection of contamination. In: Lelieveld, H.L.; M. Mosterte, A.; Holah, J. Handbook of hygiene control in the food industry. Woodhead Publishing, Cambridge, England, 2005, chapter 36, p.588-618.

12. Hawronskyj, J.M.; Holah, J. ATP universal hygiene monitor. Trends Food Sci. Technol., 8, 79-84, 1997.

13. Krysinski, E.P.; Brown, L.J.; Marchisello, T.J. Effect of cleaners and sanitizers on Listeria monocytogenes attached to product contact surfaces. J. Food Protec., 55, 246-251, 1992.

14. Murphy, S.C. ; Kozlowski, S.M.; Blander, D.K.; Bandler, D.K. Boor, K.J. Evaluation of adenosine triphosphate-bioluminescence hygiene monitoring for trouble-shooting fluid milk shelf-life problems. $J$. Food Sci., 81, 817-820, 1998.

15. Odebrecht, E.; Schmidt, H.-J.; Franco, B.D.G.M. Studies on applicability of bioluminescence in the brewery. Comparative studies and critical evaluation. Brauwwelt, 140, 1904-915, 2000.

16. Paez, R; Taverna, M.; Charlon, V.; Cuatrim, A.; Etchverry, F.; Costa, L.H. Application of ATP-bioluminescence technique for assessing cleanliness of milking equipment, bulk tank and milk transport tanker Food Prot. Trends, 23, 308-314, 2003.

17. Tydrich, L. New applications for ATP bioluminescence methods Cereal Foods World. 41(6), 463-465, 1996.

18. Velazquez, M.; Feirtag, J.M. Quenching and enhancement effects of ATP extractants, cleansers, and sanitizers on the detection of the ATP bioluminescence signal. J. Food Protec., 60, 799-803, 1997.

19. Zottola, E.A. Microbial attachment and biofilmes formation: a new problem for the food industry? Food Technol., 48, 107-114, 1994.

20. Zottola, E.A. Special techniques for studying microbial biofilms in food systems. In: Tortorello, M.L. and Gendel, S.M. Food microbiological analysis- New technologies- IFT Basic Symposia, Marcell Dekker, New York, 1997, p.315-346. 